\title{
Lo darrer agermanat (1882): un «drama històric» de Constantí Llombart
}

\author{
VICENT JOSEP EsCARTí \\ Universitat de València/IIFV \\ vicent.escarti@uv.es
}

Resumen: El presente trabajo ofrece una breve visión de conjunto de la vida y la obra teatral de Constantí Llombart (Valencia, 1848-1893), uno de los fundadores de la Renaixença en tierras valencianas, pero especialmente se detiene en el análisis de Lo darrer agermanat (1882), sin duda la aportación más sobresaliente de Llombart al teatro valenciano del siglo XIX. En este sentido, se subraya el interés por la Historia detectado en Llombart y visible en su producción literaria y, también, se pone de manifiesto la pervivencia de ideales románticos en esta obra.

Palabras clave: Constantí Llombart. Teatro. Renaixença. Valencia. Literatura catalana.

\begin{abstract}
The present work paper offers an overview of the life and the theatrical work of Constantí Llombart (Valencia, 1848-1893), one of the founders of the Renaixença in Valencia, but it stops specially in the analysis of Lo darrer agermanat (1882), undoubtedly the Llombart's most excellent contribution to the Valencian theatre of the 19th century. In this sense, it highlights the interest in the History detected in Llombart which is visible in his literary production and, also, highlights the persistence of romantic ideals in this work.
\end{abstract}

Keywords: Constantí Llombart, Theater, Renaixença, Valencia, Catalan Literature.

\section{CONSTANTÍ LLOMBART (1848-1893), ACTIVISTA VALENCIÀ DE LA RENAIXENÇA}

Si fem una ullada a la producció literària valenciana durant la Renaixença, ${ }^{1}$ resulta evident que un personatge com Constantí Llombart — que encara de-

${ }^{1}$ El present estudi s'inclou al projecte «La cultura literaria medieval y moderna en la tradición manuscrita e impresa (IV)» FFI 2009-14206, del Ministerio de Educación y Ciencia del Gobierno de España. Sobre la Renaixença valenciana, podeu consultar profitosament, entre altres, Archi- 
mana estudis monogràfics_- ${ }^{2}$ ens apareix situat de manera central; i això, encara, si no volem atorgar-li el lloc que ell segurament va reclamar, d' «iniciador» del que en la terminologia de l'època s'anomenava el «renaixement llemosí». Més enllà de preeminències i de llocs d'honor, el que potser seria més convenient dir de Llombart, és que va jugar un paper ben fonamental en fer cristal-litzar —o, per dir-ho més pròpiament, en fer aglutinar — un grup de poetes i de lletraferits de diversa qualitat que, malgrat tot, vist des de la distància, se'ns presenta com el resultat literari més brillant d'aquells anys de finals del segle XIX, i que, tenint en compte les ramificacions posteriors, s'endinsarien fins $i$ tot al segle XX.

Però, si el període de la Renaixença valenciana encara resulta fosc en molts aspectes, i només a poc a poc es van aportant noves dades que hi donen llum, no és menys cert que encara estem mancats d'un estudi definitiu sobre Llombart i la seua literatura, i també ens caldria un treball que remarcàs el seu innegable valor com a dinamitzador cultural de la València del seu temps. Tanmateix, és veritat que disposem ja d'algunes aproximacions a la seua obra i a la seua figura - elaborades algunes ja en vida de l'autor, cosa que evidencia l'admiració que li professaren alguns dels seus coetanis-, que ens permeten fer un repàs al que va ser la seua trajectòria. Així, Lluch i Soler (1879), de manera breu, ja ens oferia un panorama succint d'alguns aspectes de la vida del personatge; i, a mitjans del segle XX, el qui va ser secretari de Llombart, Ramon Andrés Cabrelles, elaborava una biografia que encara roman parcialment inèdita (Ahuir 2005). Tanmateix, tots dos textos aporten una imatge de l'escriptor fundador de «Lo Rat Penat» a cavall entre el personatge sobredimensionat i l'hagiografia. Ja a la darrera part del segle XX, dos més han estat els biògrafs seus: Manuel Lloris (1982), amb un escrit breu i no massa encertat en algunes qüestions, i José Luis Leon Roca (1995) que, en traducció a un valencià gens ortodox, publicà un altre text on utilitza les notes de Cabrelles —-sovint sense indicar-ho- $\mathrm{i}$ es perd en el retrat d'una època en què el biografiat apareix molt de tard en tard. És per això que podem dir que, ara com ara, la biografia rigorosa i ben documentada de Llombart continua sense escriure's i que la seua vida i les seues obres solament podem resseguir-les de manera parcial. No obstant això, l'esforç realitzat recentment per part de Francesc Pérez i Moragón (2005), per tal de sintetitzar-ne la trajectòria vital i intel-lectual de Llombart, podrà ser-nos una guia ben apropiada.

Carmel Navarro i Llombart, que es faria anomenar més tard Constantí Llombart en els seus papers literaris, va nàixer al carrer de la Bosseria, a València, el 8 de setembre de 1848, fill d'una família sense massa recursos. Estudià les primeres lletres a les classes per a pobres dels Escolapis, però sense massa interés, fins al punt que segurament deixà els estudis sense saber escriure ni llegir bé, $\mathrm{i}$

lés/Martí 2002; Blasco 1984 i 1988; Guarner 1983: 17-90; Roca Ricart 1996 i 2004; Sanchis Guarner 1985; Simbor Roig 1980 i 1988; Verger 1988, i Cucó 1999.

2 Sobre Llombart, vegeu el volum amb diferents aportacions sobre la seua figura i la seua obra, elaborat al voltant de l'exposició que dedica a aquest personatge l'Acadèmia Valenciana de la Llengua, i que conté l'aplec d'estudis, referències bibliogràfiques i notes puntuals més extens i complet dels que hom pot consultar fins al moment: Escartí/Roca (eds.) 2005. Vegeu també Escartí/Estrela 2008. 
començà a treballar, tot aprenent l'ofici d'ajudant d'enquadernador. Aquesta activitat el degué fer aproximar-se més encara a un veí del seu carrer, l'impressor Agustí Laborda, a la llibreria del qual va aprendre a llegir en la literatura de canya i cordeta, molt sovint de to humorístic, que llavors corria per València, destinada a un públic d'escassa formació intel-lectual. El coneixement d'aquest tipus de producció el portà a començar a escriure —en castellà—, i també sembla que provà fortuna amb un joguet còmic, intitulat En lo mercat de València, que no ens ha pervingut. Aconseguí, probablement, èxit i va redactar un «miracle» de sant Vicent Ferrer, anomenat La calúmnia castigada, que no arribà a passar la censura eclesiàstica ni es va poder representar en un dels altars que es dediquen al sant dominicà en alguns carrers i places de València, en la seua festivitat. Però d'aquests dos papers només ens han arribat testimonis indirectes. Per aquells mateixos temps va publicar alguns versos a La Gaceta Popular (Llombart 1888: 302).

El contacte amb la premsa rotativa el marcà per a sempre, i el 1867 el trobarem dirigint El Fárrago, un «Periódico sin ton ni son, ni sin saber por qué» com diu el subtítol—, del qual només arribà a publicar tres números. L'ambient polític del moment, realment mogut, i la revolució cantonalista del 1868, el convertiren en un clar defensor de les idees republicanes. Fins i tot, publicà uns Cantos republicanos, dels quals ara com ara només tenim constància del seu Himno que el Orfeón republicano de Valencia dedica al eminente orador Emilio Castelar, con motivo de su llegada a esta población, amb música del «ciudadano Enrique García», i datat a València, el 6 de març del 1871 (Llombart 1871), que no constitueix més que un full solt, del qual segurament ens queden molt pocs exemplars. ${ }^{3}$

Per altra banda, cal assenyalar que ja en aquells moments Llombart havia col-laborat amb Lo Gay Saber, «Periódich literari quinzenal fet per escriptors catalans, mallorquins i valencians» (Barcelona 1868-1869), dirigit per Francesc Pelagi Briz, i hem de pensar que el contacte amb la producció cultural de Catalunya va ser importantíssim de cara a la seua tasca posterior, atés que, sense dubte, hi descobriria nous horitzons.

Encara, l'any 1873, a València es viurien els episodis revolucionaris lligats a la sublevació cantonalista, que Llombart referí - tot i utilitzant abundós material d'altri- al seu llibre Trece días de sitio o los sucesos de Valencia. Narración histórica, el qual pretenia ser un testimoni escrit de la revolta cantonal. El volum, que meresqué l'honor de ser publicat almenys fragmentàriament en els nostres temps de nou (Llombart 1973), degué causar en la seua època un evident enrenou - els successos eren veritablement molt pròxims-, i va ser contestat pel periodista Francesc Peris Mencheta, amb la seua Refutación al folleto «Trece días de sitio o los sucesos de Valencia», publicada a València, el 1874.

Molt probablement, a partir dels esdeveniments revolucionaris que agitaren València, Llombart acabà per incorporar el seu projecte literari a una opció

${ }^{3}$ Vegeu un comentari i la reproducció fotogràfica de l'exemplar de la nostra biblioteca a Escartí / Roca (eds.) 2005: 368-369. 
concreta, que ja a Catalunya rebia el nom de Renaixença, i que Llombart s'encarregarà de «transplantar» a terres valencianes —com ell mateix assenyala en diferents llocs-, i malgrat que ja hi havia altres autors treballant en aquella recuperació, des d'altres àmbits literaris, com ara Vicent W. Querol i Teodor Llorente. O, també, des de l'àmbit del teatre, on triomfava Bernat i Baldoví, encara que aquest, segons sembla, sense uns ideals de recuperació literària comparable als dramaturgs del moment a Catalunya, ni unes directrius nacionals clarament establertes. Un aspecte que caldrà no perdre de vista, quan ens mirem la producció teatral del mateix Llombart.

Però l'afecció de Llombart per les lletres més «creatives» podem constatarla d'abans i tot dels seus interessos d'agitador polític: el 1872, amb materials propis i d'amics i coneguts, ja havia tret al carrer Niu d'abelles, una obreta de caire popular, en el pròleg de la qual es reivindicava clarament l'ús de la nostra llengua (Llombart 1872). Però serà a partir de la publicació del primer volum de Lo Rat Penat. Calendari llemosí (València, 1874), quan Llombart començarà a aglutinar al seu voltant bona part dels esforços renaixencistes que es faran a la València del seu temps.

Lo Rat Penat. Calendari llemosí, va ser, sense cap dubte, la primera revista cultural «moderna» feta des de València, i amb una clara voluntat de donar a conéixer una mostra dels productes literaris d'un costat i de l'altre de la Sénia i, encara, de les Illes Balears, a la seua comunitat lingüística. En aquest sentit, aquell projecte literari va permetre la reunió d'un grup d'autors que altrament haurien treballat sols, aillats, i potser sense l'estímul de l'empresa comuna que representà la Renaixença a partir, precisament, en bona mesura, d'aquest Calendari que dirigí Constantí Llombart. Per altra banda, aquesta aventura editorial arribà a ser una de les que major glòria li reportarien a Llombart, amb el temps; i això, en part, perquè a les pàgines de Lo Rat Penat col-laboraren en efecte els «més reputats escriptors de València, de Catalunya y de les Illes Balears», com s'indica pomposament al subtítol. Entre d'altres, cal assenyalar que aportaren les seues obres homes com Teodor Llorente, Vicent Boix, Jacint Labaila, Fèlix Pizcueta, Víctor Iranzo, Sanmartín i Aguirre, Eduard Escalante, i un llarg etcètera d'autors valencians, incloent-hi al venerable historiador Roc Chabàs. D'entre els catalans, hi col-laboraren Víctor Balaguer, Francesc Pelagi Briz o Àngel Guimerà, entre d'altres. Dels autors balears, menys presents, destaquen Jeroni Rosselló i Tomàs Forteza, al costat de Marià Aguiló. En definitiva, el bo i millor de la Renaixença va publicar al Calendari llemosí que va dirigir Llombart entre els anys 1875 i 1880, i que deixà en mans del seu deixeble i amic Josep Maria Puig Torralba, els anys 1881-1882, tornant a figurar Llombart com a codirector en companyia de Puig el 1883, i encarregant-se'n de bell nou en solitari el 1884, darrer any en què tenim constància de l'aparició d'aquesta publicació. No va ser, per tant, el fruit d'una inspiració momentània, ni tingué la brevíssima durada que era habitual als projectes d'aquell període. Lo Rat Penat. Calendari llemosí, va ser una línia d'actuació editorial que va durar almenys deu anys, i que representa, sense cap dubte, un dels majors esforços per divulgar les idees renaixencistes entre els valencians del moment. Per altra banda, a pesar de les concessions a la literatura més popularista - a què tan aficionat era Llombart—, se'l pot considerar un treball representant de les posicions clarament cultistes que planaven en aquell mo- 
ment per les escrivanies més destacades dels autors de la Renaixença (Escartí 2005; Estrela 2005).

Sense Llombart i el seu Calendari llemosí, certament, la Renaixença a València no hauria estat la mateixa: l'impuls cultural i social del moviment passà, en bona mesura, per les pàgines que redactà i compilà Constantí Llombart, unes pàgines on col-laboraren, com hem vist, les veus més notòries del panorama literari i històric de València, i que es varen enriquir amb les aportacions de figures destacades de Catalunya i de les Illes Balears. Aquest nucli format pel Calendari llemosí — del qual n'era nexe d'unió Llombart- en gran part va ser el responsable de la creació de «Lo Rat Penat, Societat d'amadors de les glòries de València i son antic Realme», el 1878, de la qual entitat, per cert, el Calendari llemosí donarà informacions abundants en les seues pàgines, a més de publicar en elles part de les obres premiades als Jocs Florals que cada any celebrava l'entitat valencianista.

El Calendari llemosí que dirigiren Llombart i Puig i Torralba va conservar durant els deu anys de la seua existència la mateixa tipologia i format, amb una distribució dels materials publicats molt semblant. Aquests materials literaris eren, bàsicament, poesies que només en comptats casos no estaven escrites $e x$ professo per al Calendari. També apareixen proses de ficció — sovint historicistes-, edicions de documents i assajos de temes històrics i, també, lingüístics. Tot i aquest interés per la llengua, Llombart no arribà a adoptar un criteri ortogràfic per a la seua publicació, i les oscil-lacions són, certament, notòries, amb un total respecte als criteris dels autors que hi participen. Amb tot i els defectes que es podran trobar, i malgrat les llacunes insalvables, el Calendari llemosí va representar un esforç cultural molt notable, a la València d'aquells anys, i segurament l'hem de situar a la base d'altres projectes culturals i editorials de Llombart (Escartí 2005). De fet, és a les pàgines del Calendari llemosí on es poden trobar apuntades les línies principals de l'actuació llombartiana respecte a la Renaixença:

Nos habem proposat portar-ne a cap lo renaiximent de les lletres llemosines y, per més que siguen curtes les nostres forçes, no tenim que deixar, per a conseguir-ho, pedra per tocar, com a vegaes solem dir.

A aquest objecte tenim pensat, si bé per a més abant, lo establir en València un centre a hon se concentraren tots los disgregats elements literaris llemosins, y vórer si, per este medi, se logra donar-li tot l'impuls que-s necessita per a ixir-ne en sol en esta dificultosa però lloable empresa.

Aixís ho manifestàrem a molts de nostres amichs, y entre los quals lo Sr. Carreras, creguent qu-aquest pensament debia ser realiçat quant en ants, ho anuncià en lo Diario de Valencia, y copiant-ho tots los demés de la població y alguns de Catalunya, s'ocuparen aquells dies ventajosament de la idea.

Los Fills de la Morta Viva, qu este serà lo nom que l'Acadèmia de lletres llemosines ha de dur, podrà, ab l'esforç de tots los aymadors de nostres glòries, eixecar-ne lo pendó de la nova crehuada fins lo punt que.n lo dia li correspon per dret ocupar-ne. D'ella, ab l'activa cooperació dels intel-lijents, podrà ixir- 
ne una bona Gramàtica llemosino-valenciana, que tan utilosa pot ser-nos; una Ortografia, millor que lo breu ensaig que tenim a punt donar al públich; podríem també empéndrer lo perfeccionament de lo Diccionari de lo Sr. Joseph Escrig, que tant podia millorar-se; podríem anar estudiant les reformes hui compatibles en l'estat de nostra llengua; podríem publicar-ne un periòdich per lo promte y, tal volta, més enllà, la «Biblioteca llemosina», composta de les principals obres llemosines, antigues y modernes (Lo Rat 1876: 13).

Com es pot veure, al renaixement literari que projectava Llombart es trobaven els elements necessaris per tal de codificar un idioma - ortografia, diccionari i gramàtica-, hi havia la constitució d'una empresa editorial que aportàs models clàssics als autors contemporanis —o obres actuals d'especial vàlua- $\mathrm{i}$, encara, hom pensava a editar un periòdic - segurament El pare Mulet, com veurem- que esdevindria el mitjà per establir els contactes entre els membres d'aquell projecte cultural i un espectre ampli de la població. Un projecte al qual Llombart va dedicar tota la seua vida i que, en bona mesura, va arribar a veure culminat, amb l'afegit, encara, d'altres actuacions que potser de bon començament no tenia previstes.

Així, Constantí Llombart, va ser conscient que la recuperació cultural i lingüística dels valencians passava per conéixer els textos literaris del passat, i en aquest sentit cal recordar l'edició de les Obres festives compostes segons antiga, general y molt rahonable tradició pel Pare Francesch Mulet, frare profés dominico (València, 1876), El procés de les olives e disputa dels jòvens hi dels vells, fet per alguns trovadors que avant se nomenen (València, 1877), o les Alabanzas de las lenguas, de Martí de Viciana. Encara, sabem que el mateix 1877 es dedicà a transcriure, amb la intenció de fer-ne una reedició, Les trobes en lahors de la Verge Maria (1474), a partir de l'exemplar conservat a la Biblioteca de la Universitat de València, que no arribà a rams de beneir (Leon Roca 1995: 138-139).

Però els interessos de Llombart no eren només els erudits, en aquells anys, $\mathrm{i}$ testimoni d'això és el seu periòdic El Pare Mulet. Semanari impolític y bou solt, que aparegué el 8 de gener de 1877, encara que anteriorment va conéixer un «Número prospecte», en una data que no podem precisar però que segurament seria de finals del 1876. Aquest periòdic s'acostava a altres setmanaris anteriors i pretenia clarament un públic lector popular, com es pot veure pel registre de llengua que s'hi emprà (Martí Mestre 2005). Per altra banda, aquest setmanari ens permet veure un Llombart jocós i crític amb la societat, i en especial amb els seus dirigents, cosa que li generà problemes amb les autoritats, que acabaren per prohibir aquell periòdic, i, en especial, per les seues crítiques a la política del marqués de Campo. Tanmateix, el 28 d'abril de 1877 apareixia, en forma de continuació del setmanari El Pare Mulet, una nova publicació periòdica dirigida per Llombart: El Bou solt, que enllaçava directament amb l'anterior. En aquest, Llombart es mostrarà crític, però menys incisiu que en l'anterior, i malgrat la seua moderació, el periòdic eixí al carrer per darrera vegada el 27 d'octubre del 1877, sense que resten clares les causes per les quals no va tornar a aparéixer, com ja va destacar Ricard Blasco (1985). 
Altres treballs literaris seus d'aquells anys són: la traducció al castellà de $L a$ masia dels amors, de Pelagi Briz, i La mort de Neró, de Víctor Balaguer, i la reedició dels setmanaris El Sueco (1847), El Tabalet (1847) i La Donsayna (18441845), publicats per Bernat i Baldoví, Josep Maria Bonilla i Pasqual Pérez Rodríguez, que varen tornar a veure la llum el 1877 (Navarro Cabanes 1928: 48-50). Llombart va publicar, també, Tabal y donsayna (València, 1878) i Tipos d'auca (València, 1878), que eren uns reculls de textos de caire divertit i on varen participar, a banda del mateix Llombart, autors com Escalante, Josep d'Orga, Josep Bodria, Lluch i Soler, Roig i Civera, Víctor Iranzo, Lladró i Mallí, Joaquim Balader i alguns altres que, en general, es corresponien amb la nòmina de col-laborados valencians del seu Calendari llemosí. Del mateix estil, i d'aquell mateix any és Abelles y abellerols. Sent y un epigrames (Llombart 1878).

Però l'activitat de dinamitzador cultural de Llombart va arribar al seu zènit en crear-se a València «Lo Rat-Penat», el 1878. Aquella «Societat d'aimadors de les glòries de València i son antic realme» que va iniciar Llombart amb el vistiplau dels patricis valencians de la burgesia benpensant, prompte va passar a ser dirigida pel sector més conservador i monàrquic - Llorente i els seus amics (Roca Ricart 2007: 82-89) — i Llombart, que durant un bon temps va seguir confiant en la institució que ell mateix havia animat a crear —almenys així s'infereix dels comentaris seus al Calendari-, arribà a pensar en provocar-hi una escisió, quan plantejà, anys més tard, la creació de «L'Oronella», la qual perseguiria els mateixos objectius de «Lo Rat Penat», però des de posicions segurament més republicanes i liberals. En qualsevol cas, i mentre això arribava, Llombart va continuar amb els seus projectes periodístics, i, el 1880, va traure El Dotor Cudol, periòdic satíric com les anteriors empreses seues i de poca durada també.

Tanmateix, l'aportació més «sòlida» de Llombart a la Renaixença, potser siga Los fills de la morta-viva, publicada a València, el 1883 (Llombart 1883), una obra contundent que havia estat premiada en projecte als Jocs Florals de «Lo Rat Penat» de 1879, i que és en definitiva un diccionari biogràfic dels escriptors valencians, des de Carles Ros i alguns altres homes del XVIII, fins al moment en què Llombart escriu. Tot i que Llombart s'unia així a la tradició valenciana de grans bibliògrafs il-lustrats com Josep Rodríguez, Vicent Ximeno i Just Pastor Fuster, cal assenyalar que el nostre autor no va ser ni tan rigorós ni tan «erudit» com pretenia, admetent autors que no havien escrit res en la llengua pròpia del país, i plagiant materials d'altri, sense indicar-ho en nota. No obstant, això no ha de restar importància a un paper tan profitós encara com aquell, que si evidencia alguna cosa és, sobretot, la fe del seu autor en la seua llengua pròpia, i que aquell va saber trascendir així el simple camp de la poesia, el teatre o la prosa de creació, per arribar a l'assaig biobibliogràfic, és a dir, a una matèria erudita.

L'activitat de Llombart, els anys següents, serà també ben dispersa: col-laborà al setmanari La Moma (1885-1886), dirigit per Rafael Maria Liern i Ramir Ripollés, i sabem que va aportar alguns textos seus a la Corona poética teixida en honor de la Musa del Xuquer (València, 1887), dedicada a Josep Bernat i Baldoví.

En un altre sentit, cal assenyalar que el 1886, va arribar a guanyar la Flor Natural dels Jocs Florals de «Lo Rat Penat» amb el poema La Copa d'Argent. Lle- 
genda del segle XVI, que es publicaria l'any següent (València, 1887). És segurament un dels escrits literaris més destacables de Llombart i mostra, entre altres coses, l'interés dels homes de la Renaixença per conéixer el passat històric del país. En especial un món medieval -més o menys ampli-, que des de la distància era idealitzat i venia a encarnar perfectament els ideals de pàtria, fe i amor, que era la divisa dels poetes i literats de la Renaixença i que provenia del Romanticisme. Però, en el nostre cas, aquesta admiració per un passat poc o gens conegut, es perllongava fins al segle XVIII, en què l'arribada dels Borbons acabà $\mathrm{amb}$ el funcionament del sistema foral. Els Borbons, per altra part, era la dinastia regnant contra la qual es trobaven en peu de guerra els republicans com Llombart. Per tant, tot un cúmul de circumstàncies feia possible que el passat medieval i foral fos vist pels homes liberals del XIX com un referent cultural, polític i social a tenir en compte, i, sobretot en l'àmbit literari, com un model que calia imitar. Des dels clàssics medievals al pare Francesc Mulet, del XVII, els autors valencians antics eren «venerats» per Llombart, que intentà, en la mesura de les seues forces, recuperar-los, tot editant, sempre que va poder, les seues obres. A aquells autors —elevats a la categoria de símbols nacionals- era a qui calia imitar, des de l'ideari llombartià.

Per això resulta lògic que Llombart, en el moment que ha de presentar-se als Jocs Florals de la institució que ell havia fundat, no dubte a fer-ho amb una recreació historicista, tan del seu gust, però, també, tan agradosa segurament a la resta dels homes renaixencistes que conformaven el jurat d'aquell certamen. El tema històric, encara, permetia a Llombart la utilització d'un registre més culte -allunyat de les formes col-loquials i populars de bona part de la seua producció poètica i periodística-, que també semblava el més adient a aquelles mostres «culturalistes» que eren els certàmens jocfloralescos. La copa d'argent, subtitulada «Llegenda del segle XVI» pel mateix Llombart, en vers i amb expressions que de vegades posen de relleu la dificultat d'aquells primers recuperadors de la nostra llengua, a l'hora d'escriure-la, va rebre per unanimitat la Flor Natural, «premi d'honor y cortesia», que n'era el guardó més valuós. El jurat, integrat per Fèlix Pizcueta, Eduard Pérez Pujol, Joaquim Balader, Joan de la Creu Martí, Carmel Calvo i Rodríguez, Josep Espí i Juli Cebrian, li atorgaren aquell premi en atenció a

la originalitat del asunt, les imàgens y pensaments enèrgichs unes vegades y delicats altres, que l'avaloren; la bella y correcta forma dels seus versos, lo sabor d'època, coneiximents històrichs que l'autor revela, y sobre tot, l'entusiasme y esperit de valencianisme qu·en ella resplandixen (Llombart 1887: 5-6).

Aquella valoració degué deixar ben pagat a Llombart, que no dubtà a fer estampar una còpia de l'acta del jurat a la capçalera de la seua publicació.

Llombart, amb La copa d'argent aconsegueix crear una certa tensió narrativa i permet al lector interessar-se per una composició poètica que, altrament, no arribaria a captivar-lo, atés que els personatges no tenen una força espectacular i, vistos des de la nostra òptica, pequen de semblar massa «reconstruccions» poc creïbles. Llombart, però, amb episodis que recorden el to èpic, encara que, alhora, amb algun lleuger diàleg més propi d'un sainet que d'una narració històrica 
en vers, reïx en el seu intent, i ho fa fins al punt que encara en els nostres dies aquella seua obra «es deixa» llegir amb un relatiu gust. Adobada la historieta d'un vernís romàntic molt propi del moment — Llombart hauria llegit, sense dubte, la narrativa històrica de Vicent Boix-, li sobra, potser, l'aparat pretesament crític de notes històriques on l'autor deixa entreveure la seua passió per la història i per l'escorcoll dels arxius - la font d'on probablement derivava bona part del seu amor a la pàtria dels valencians-, però que no aporten res al desenvolupament de l'argument de La copa d'argent. Aquella història ambientada a la Valencia del Renaixement, amb amors difícils i situacions de matrimonis imposats, potser revela algun trassumpte relatiu al mateix autor que, ara com ara, no ens trobem en situació d'afirmar. En qualsevol cas, és un text viu i amb suficient força i, certament, un dels millors escrits de Llombart. De fet, per a l'editor més recent d'aquesta composició, Rafael Roca, aquest escrit «suposa un gran punt d'inflexió en la producció lírica valenciana de Constantí Llombart, no sols pel canvi temàtic que comportà (...) sinó per la millora de la qualitat literària, estilística i lingüística que suposà respecte als llibres anteriors» (Roca Ricart 2006).

Però una de les darreres empreses llombartianes de major abast fou la publicació del Diccionario Valenciano-Castellano de Josep Escrig, (València 1887), revisat i augmentat per ell mateix, per a la qual cosa comptà amb l'ajut de Ramon Andrés Cabrelles. Cal dir que Llombart va afegir un «Ensayo de ortografía lemosino-valenciana», que en realitat era la traducció d'un text en valencià amb què havia obtingut un premi als Jocs Florals de «Lo Rat Penat», del 1880 (Guardiola i Savall 2005).

També d'aquell mateix any és Valencia antigua y moderna. Guía de forasteros (València, 1887), un text que es troba ple de plagis provinents d'un treball que per aquell temps era manuscrit i inèdit, de Marc Antoni d'Orellana, i que portava el mateix títol.

Llombart, encara, en recuperar el sector més liberal les regnes de «Lo Rat Penat», va temptar de publicar Lo Rat-Penat. Periòdich Lliterari Quincenal (1884-1885), que va ser considerat «Orgue oficial de la societat de amadors de les glories valencianes redactat per escriptors valencians, catalans y mallorquins», i que fou de brevíssima durada (Blasco 1985).

Constantí Llombart, encara, el trobem publicant, el 1892, Patriotisme y llibertat, una poesia premiada en un certamen celebrat a Castelló de la Plana aquell mateix any; i traduïnt en castellà Aires de mi tierra. Poesías gallegas (Madrid 1892), de Manuel Curros Enríquez (1851-1908), amb pròleg de Vicent Blasco Ibáñez. També, del 1892 és un opuscle que ha passat bastant desapercebut: Pullitas y cuchufletas. Ramillete de ciento y un epigramas. ${ }^{4}$

Finalment, Llombart va morir a València el 1893 i el seu cadàver va ser l'objecte d'enfrontaments entre els republicans de Blasco i els sectors més dretans de la societat, que, encapçalats per Llorente i els seus amics de «Lo Rat Penat»,

${ }^{4}$ Es conserva un exemplar d'aquest llibre a la Biblioteca Nacional de Madrid (sign. 1/245487). Agraesc aquesta informació a l'amic J. Enric Estrela. 
també volgueren retre-li honors al difunt. La notícia del soterrament era referida a l'Almanaque de Las Provincias para 1894, amb aquestes paraules:

La muerte del conocido escritor D. Constantino Llombart, ocurrida el último día de marzo, dió pretexto para hacer un alarde de irreligiosidad a los partidos avanzados, a los que estaba afiliado el popular poeta. Aprovechando la circunstancia de haber fallecido sin recibir los auxilios de la iglesia, se le preparó un entierro civil, al que invitaban en primer lugar el presidente del Consejo federal de la región valenciana y el comité municipal de este partido, en una esquela desprovista de toda fórmula religiosa. Muchas personas amigas del difunto se retrajeron de asistir al entierro; la sociedad del Rat-Penat, cuya fundación había sido iniciada por él, desistió de prestar el homenaje preparado a su fundador, y la corona destinada a figurar sobre el féretro, fue colocada en el altar de la patrona de Valencia. Al entierro asistieron sólo políticos exaltados, y el cadáver, conducido en hombros, iba cubierto por la bandera tricolor (Almanaque 1894: 47).

Ara com ara no es pot saber amb total certesa quina hauria estat la voluntat del finat. Per un costat, els republicans feren bandera del seu cos i de la seua figura, encara que gens faria Blasco Ibàñez, després, per la causa que tant va animar Llombart al llarg de la seua vida. Per altra banda, hi ha testimonis evidents que allunyen Llombart d'aquelles idees «progressistes» i, en especial, de l'ateisme. Mostra d'això són les paraules de Joan Esteve, en un homenatge publicat a Castelló, amb evidents senyals de voluntat de recuperar la imatge de Llombart per a causes no republicanes:

De res serviran tots los esforços fets per los que han volgut explotar lo nom de Llombart en benefici d'una causa política-social. Dins de pochs anys ningú recordarà d'ell ni sa filiació ni los seus escrits polítichs; sempre se llegiran en gust les sehues poesies, inspirades en totes les més santes afeccions que nos fa sentir la pàtria, y l'història del renaiximent lliterari li farà justícia, cuant escriga sobre la llosa de son sepulcre «Así dorm lo més bon valencià» (Homenage 1893: 10).

Per damunt de la ideologia de l'autor i dels episodis més o menys coneguts de la seua vida, és clar que ens va deixar una obra interessant, la qual, unida a la seua producció teatral — de la qual parlarem tot seguit-, dóna mostra dels inicis difícils de la Renaixença al nostre país. De fet, la producció llombartiana es ben representativa dels espectres a què un escriptor valencià havia d'arribar, i per això la seua obra pot ser agrupada en dos grans blocs — sovint amb punts de contacte- que, si deixem de banda els seus escrits en castellà, corresponen al tipus de públic a qui, en principi, anaven destinats aquells seus escrits. El primer d'aquells conjunts seria el constituït per la literatura de marcat caràcter «popularista» - versos més o menys satírics i amb connotacions eròtiques i tot; peces de teatre amb clara voluntat còmica...-, editada sovint amb grafies castellanitzants i amb freqüents formes lingüístiques més col-loquials (Llombart 2005); mentre que el segon dels grups inclou una producció més heterogènia, més «cultista» $\mathrm{i}$ destinada a lectors que estaven més avesats a llegir papers en la nos- 
tra llengua, com demostra fins i tot la diferenciació en el nivell lingüístic que Llombart fa servir. Per exemple, Lo Rat Penat, en tant que revista anual llemosinista - per usar una terminologia cara al seu fundador-, va ser una mostra dels interessos culturals més elevats de l'autor valencià, al costat de projectes com l'edició i l'ampliació del Diccionari d'Escrig, l'obra bibliogràfica Los fills de la Morta Viva i, encara, dues obres de Llombart que podem considerar de més volada literària, formal i lingüística: el poema La copa d'argent i la peça teatral Lo darrer agermanat, amb clares reminiscències romàntiques, per altra banda. Al costat d'aquesta tasca d'erudit, editor i escriptor, l'obra per antonomàsia a què va aspirar el nostre autor fou la creació d'una «acadèmia» — d'una societat valencianista dedicada a l'estudi i el conreu de la llengua-i que, si bé al llarg de la seua vida va adoptar diverses fórmules i denominacions, acabà quallant en «Lo Rat Penat, Societat d'amadors de les glòries de València $i$ son antic realme», una institució venerable que encara perdura fins als nostres dies, i que ha sabut subsistir, tot i que no sempre amb les orientacions més adients als temps que li ha tocat viure i, encara, traïnt nombroses vegades els desitjos i les idees prístines del seu fundador i dels homes que en aquell temps ajudaren a donar-li vida, com ara el mateix Teodor Llorente, Jacint Labaila, Fèlix Pizcueta i d'altres (Igual Úbeda 1959 i DD. AA. 2000).

\section{L’ACTIVITAT TEATRAL LLOMBARTIANA}

El teatre que va elaborar Llombart al llarg de la seua vida va ser sempre per circumstàncies molt concretes i, segurament, quasi mai per una autèntica vocació d'autor teatral, com ja ha destacat Gabriel Sansano (2005). En definitiva, Llombart, com ja hem dit més amunt, coneixia el poder de transmissió d'idees i de pensaments que podia assolir la representació teatral, especialment en una societat tan poc alfabetitzada com la seua, i se'n servia, quan ho necessitava, en atenció a difondre alguna idea determinada entre els espectadors.

Però, per altra banda podem veure que el teatre sembla que va ser una de les primeres activitats de Llombart al món de la literatura, si fem cas de les informacions aportades pels biògrafs i si donem per certes - encara que no sembla que s'editaren mai- dues peces seues de poca volada i ja esmentades més amunt: En lo Mercat de València i La calúmnia castigada (Leon Roca 1995: 25). Al marge d'aquestes obres jovenívoles, la primera creació teatral de Constantí Llombart va ser Justicia contra justicia (València, 1872), que va ser un al-legat contra la pena de mort i on els personatges eren clarament al-legòrics i imbuits de filosofia, cosa que sembla apuntar que, si aquell treball de Llombart arribà a conéixer l'èxit, degué ser més pel rerefons de tot plegat que no per la mateixa peça teatral. L'obra, representada al Teatre-Café de Russafa —un àmbit popular, doncs-, l'agost del 1872, es va tornar a editar el 1881, acompanyada d'un pamflet amb al-legacions contra l'esmentada pena capital, de la mà de l'advocat Rafael Ramos. En opinió de Gabriel Sansano,

malgrat que al final de l'obra l'autor dóna algunes idees sobre la caracterització dels personatges, pel seu format i pel fet d'estar totalment subordinada al 
seu discurs sobre l'abolició de la pena de mort, és una peça difícil de representar, que tan sols podia ser ben rebuda pels partidaris de la causa (Sansano 2005: 188).

Tanmateix, la seua escenificació no degué ser un fracàs entre aquell públic predisposat a les idees republicanes, perquè Llombart, poc de temps després, va escriure - i es va representar al mateix lloc-La esclavitud de los blancos (1873), un drama on l'autor inistia en les seues reivindicacions de caire social, atés que demanava l'abolició de les quintes, una circumstància que ell mateix hauria de patir. De manera que, com assenyala Sansano (2005: 189), «sense abandonar la reivindicació d'uns ideals concrets, el seu teatre inicial passa de l'abstracció al-legòrica a la concreció en un rerefons de fets coetanis». En definitiva, aquestes dues obres de Llombart s'emmarcarien en els moviments despertats per les idees republicanes que va professar l'autor, i tindrien un destinatari popular claríssim, aprofitant circumstàncies sociopolítiques concretes del moment.

Més avant, l'any 1876, Llombart va portar a l'escenari, en col-laboració amb Lluís Cebrian i música del mestre Cortina, La sombra de Carracuca (València, 1876), un text més bé intrascendent que prenia com a referència un «juguete cómico-lírico» que degué assolir una gran fama, i que portava per títol Carracuca!, obra de Rafael M. Liern, estrenada a València el 1873, i on, com ja s'ha indicat, Liern «es decanta ací per adaptar el quadre de costums a la moda del teatre musical, i li dóna una aparença de sarsuela» (Sansano 2005: 192). Segurament, Llombart i Cebrian pretenien renovar-ne l'èxit del personatge creat per Liern —un rufià de poca monta—, que seria representat en les dues ocasions pel mateix actor: Ascensi Mora, el qual certament devia dotar l'obra de la gràcia que sobre el paper li manca i que, sense dubte, va provar amb aquest text llombartià de repetir l'èxit de públic que hauria assolit anteriorment.

Aquell mateix any, encara, Llombart va fer representar i publicar un altre seu text: La corona del martirio, una poc coneguda adaptació d'un text que segurament era original de Eugéne Scribe, un autor francés molt prolífic del segle XIX, i que era famós pels seus «llibrets» per a òperes (Sansano 2005: 190-191). Del text del fundador de Lo Rat Penat, és ell mateix qui ens dóna pistes sobre la seua gènesi i evolució posterior. Així, al pròleg que hi adjunta, fa veure que Joaquim Martínez Imbert posseïa un manuscrit — potser una versió de l'obra francesa, de la qual Llombart no en cita l'autor - i va ser aquest qui demanà a Llombart que en fes una versió per a l'escena valenciana. En estrenar-se aquesta, alguns espectadors que havien acudit al teatre de Russafa no degueren quedar massa satisfets, perquè coneixien una versió anterior que del mateix text havia fet l'argentí Ventura de la Vega. Llombart, segons afirma en aquell pròleg, no en tenia constància. Molt probablement, per tant, ens trobem davant una versió de L'Artiste (1821), del francés Scribe, i sabem que Ventura de la Vega, per la seua part, el 1839 va donar a l'estampa, a Madrid, Un alma de artista. Comedia en tres actos adaptada al teatro español, que potser també va beure en les mateixes fonts, tot i les evidents diferències. Al text de Llombart, l'acció se situa a Florència, el 1550, i molt possiblement pel fet de tractar-se d'un text d'ambien- 
tació històrica, això el degué fer més atractiu a Llombart, el qual sempre havia mostrat una clara predisposició als temes historicistes i, més específicament, al conreu del drama històric, com demanà en més d'un lloc, i com ell mateix també tractà d'assajar a Lo darrer agermanat.

Després d'un llarg parèntesi de set anys sense publicar teatre, Llombart tornà a endinsar-se en aquest gènere, de la mà de Lo darrer agermanat, del qual parlarem tot seguit i al qual, però, no li podem suposar un gran èxit, atés que Llombart no tornà a fer cap provatura més d'aquell signe i sí que retornà a escriure en valencià, i en la línia del teatre còmic, amb L'agüela Puala (València, 1886), amb la col-laboració de Ricard Cester i amb música del mestre Cortina novament. En aquest cas, Llombart i Cester feien una adaptació de La sonàmbula, de V. Bellini i F. Romani, i el text es va editar com a suplement del setmanari La Moma, sense que ara com ara se sàpia amb claredat si es va arribar a representar i si, com afirmen alguns autors, l'obra ja s'havia publicat uns quants anys abans (Sansano 2005: 194-195).

Finalment, Llombart, amb la col-laboració del seu secretari, amic i biògraf Ramon Andrés Cabrelles, va publicar La Cruz Blanca (València, 1890), una obra on es connecta amb la realitat circumdant, tot tractant de publicitar la societat de caràcter humanitari que el mateix Llombart va crear - i que portava per nom «La Cruz Blanca», s'inspirava en «La Creu Roja» i centrava els seus esforços a València-, la qual pretenia ajudar a la població davant l'epidèmia de còlera que assotava València en aquell temps. L'organització benèfica pretenia recaptar fons a través de la representació d'aquella obreta que destacava els valors de la medicina moderna, per damunt de les supersticions encara arrelades en bona part de la societat local del moment. És per això que segurament l'obra es va representar simultàniament a dos espais teatrals, el Teatre-café del carrer de Russafa i «un altre espai denominat Teatro Peral» (Sansano 2005: 195).

L'activitat teatral de Llombart, encara, caldria completar-la amb les diferents obres que va adaptar o traduir (Sansano 2005: 187-188) i aquelles que, ara com ara, resten inèdites o il-localitzades, com El Mesías prometido o La joya de Carcagente, sobre la qual, com indica Sansano (2005: 187), hi ha la notícia de la seua existència en versió impresa (Llombart 1879-1883: 770), però no localitzada fins ara. Tanmateix, podem afegir que molt probablement podríem datar-la el 1881, atés que La joya de Carcagente o Hallazgo de la Virgen de Aguas Vivas, — títol que porta el text al manuscrit conservat a València—, és un «auto» en tres actes i en vers que sembla que es va estrenar el 24 de febrer de 1881, a Carcaixent, aprofitant la inauguració del Teatro Liceo d'aquesta localitat de la Ribera (Fogués Cogollos 1902: 36). No seria estrany que el text, pel seu evident localisme, hagués restat manuscrit, tot i que Llombart albergàs l'esperança de veure'l publicat algun dia. En qualsevol cas, sabem que una còpia efectuada per l'erudit Salvador Carreres Zacarés es conservava a l'Arxiu Municipal de Carcaixent, juntament amb una còpia del primer acte, que es troben ara com ara il-localitzades, després de la riuada que afectà aquell arxiu el 1982. ${ }^{5}$ Recentment,

\footnotetext{
${ }^{5}$ Vull agrair aquestes informacions al carcaixentí Bernat Daràs Mahiques.
} 
però, al Fons Carreres de la Biblioteca Valenciana ha estat localitzat un altre manuscrit. ${ }^{6}$

\section{LO DARRER AGERMANAT, UN PUNT CULMINANT}

Al pròleg de Lo Rat Penat. Calendari llemosí per al any 1874, Llombart, que fins aquell moment havia estrenat dues obres, en castellà, de temàtica sociopolítica, Justicia contra justicia, el 1872 i La esclavitud de los blancos el 1873 , com hem vist més amunt, donava clars indicis de conéixer la influència que el teatre com a mitjà de comunicació podia assolir entre el poble. Per això, el seu punt de vista sobre la producció teatral era ben concret: per un costat es queixava de «l'atrás en que es troba», afegint-se a les queixes que ja abans Teodor Llorente havia denunciat a Las Provincias; i, per un altre, explicitava els camins que en el futur, des del seu punt de vista, haurien de seguir els homes de teatre a València:

convindria qu'els autors se posaren acórdes en la part del llenguatje de les obres llemosines, y, eletjint arguments de carácter verdaderament valenciá, s'ensatjaren d'un modo formal, per diro aixina, en lo drama histórich, ahon tenen molt terreno per esplorar encara; y en la comedia de costums (Lo Rat 1874: $15)$.

$\mathrm{El}$ «drama històric», per tant, era el gènere que més podia atraure Llombart. Interessat de sempre en la història valenciana, com ja hem assenyalat, va elaborar alguns treballs basats més o menys en la investigació, i aspirà i tot a ser cronista de la ciutat de València. A més, al seu Calendari llemosí sempre donà cabuda a articles de caràcter històric $\mathrm{i}$ ell mateix s'encarregà de transcriure $\mathrm{i}$ publicar documents (Estrela 2005). Per altra banda, cal recordar que bona part de la millor producció lírica valenciana de Llombart presenta motius de caire històric, com al cas de La copa d'argent - esmentada més amunt i reeditada fa poc (Llombart 2006b: 252-288)—, però també, entre altres, en composicions com Lo compromís de Casp — premiada el 1891 als Jocs Florals i també reeditada recentment (Llombart 2006b: 397-406) — o l'ara com ara perdut poema èpic $L a$ mort del Conqueridor, que havia rebut igualment un guardó el 1888 (Roca Ricart 2006: 63). L'interés per la Història com a punt d'inspiració era, per altra banda, ben «romantic».

S'hauria de tenir en compte, també, i com ha posat de relleu molt encertadament Sansano (2005: 194), que a l'Almanaque de las Provincias per a l'any 1881 es donava notícia de com a «Lo Rat Penat», l'any 1880 , es tractaren dos temes en debats de la secció de literatura que, sense dubte, degueren influir en el treball de Llombart, atés que ell mateix, també, hi va participar: «Pasat, present y pervindre del teatre valencià», $\mathrm{i}$ «Orige de les Germanies». Escena i moviment

${ }^{6}$ La signatura d'aquest manuscrit és Carreres 23/H-13. Vull deixar constància ací del meu agraïment a l'amic Juan Galiana, de la Biblioteca Valenciana, que m'ha facilitat gentilment la notícia. 
agermanat, doncs, foren dues de les preocupacions erudites i d'actuació social d'aquell per a Llombart. Un moviment revolucionari i «popular» que, sense cap dubte va enllaçar amb els ideals romàntics i, després, com una prolongació natural, amb els liberals i els renaixencistes i, més especialment, amb aquells somnis republicans que podia imaginar el mateix Llombart.

Encara, per altra banda, resulta evident que el conflicte armat de les Germanies havia de representar per als homes de la Reinaxença, com a bons romàntics, un punt d'interés: hi havia les figures dels herois, la defensa d'uns ideals més o menys correctament interpretats des de la distància dels segles i, encara, hi havia el referent més fresc de les guerres carlines o les revoltes, més pròximes encara (els incidents de la I República a València, per exemple), que podien fornir d'imatges viscudes de prop la reelaboració d'uns fets històrics que, en bona mesura, es podien reconstruir fàcilment $i$ de forma directa. La presència de l'Encobert, una figura misteriosa, segurament encara exercia una major atracció sobre alguns d'aquells literats. El cronista de València Vicent Boix —admirat per Llombart-, va escriure una novel-la que portava per títol El Encubierto de Valencia i es publicà el 1859. Uns anys abans, el 1840, Garcia Gutiérrez havia publicat un text dramàtic amb el mateix títol, i el 1877, Francesc Palanca i Roca portaria també a l'escena els episodis finals de la Germania, amb luxe d'imaginació i d'alteració de la història, i sempre al servei d'una major tensió creativa. A Fueros y Germanías o El Encubierto de Valencia, el text de la qual es troba en valencià, Palanca — republicà i federalista—, volgué mostrar el comportament d'aquella revolta com un antecedent de les revolucions del seu segle, amb dos finals diferents: en el primer, la justícia divina seria l'encarregada de castigar els dolents - com també es deixa veure en el drama de Llombart que ara veurem-; en el segon - que es portava a termini si la sala es trobava plena de gents populars-, era un agermanat qui castigava amb la mort el criat del marqués, tot acabant la representació amb un crit en contra dels tirans, és a dir, de l'opressió del que llavors ja més que «senyors» s'havien convertit en «senyorets» (Atienza 2000: 25).

En aquesta línia hem de situar l'obra de Constantí Llombart, del 1882, Lo darrer agermanat, ${ }^{7}$ en la qual també l'acció transcorre en els últims moments de la Germania i, més concretament, en l'enfrontament final on morirà Vicent Peris, assetjat a sa casa de València, que després seria assolada i el seu solar sembrat de sal, com a càstig exemplar. Llombart, per tal de representar aquells últims instants de la guerra de les Germanies, assolirà moments de gran dramatisme —en especial quan el discurs s'enfilarà cap al vessant històric i polític_- i adobarà la trama amb elements sentimentals de tipus familiar i personal, que li permeten donar explicació a algunes incògnites de la realitat pretèrita. Però, sempre, des d'una menor fabulació respecte a personatges i accions, i procurant ajustar-se en la mesura del possible a les informacions que havia extret, sense dubte, dels cronistes que va usar com a base del seu text teatral, i la informació dels

7 L'obra de Llombart ha conegut, modernament, dues edicions. La primera, per Atienza (2005: 45-87), amb retocs ligüístics poc ortodoxos. La segona, a cura d'Escartí (Llombart, 2006a), que serà la que prendrem com a referència a les nostres citacions. 
quals va oferir en notes a la fi del seu text. A la fi, però, els ideals de Llombart semblen també sobreposar-se a la pròpia ficció històrica, de manera que aquells seus agermanats no acabarien morint inútilment, sinó que fan l'efecte de deixar aquest món tot esperant el futur. Així, Peris, en un moment donat exclamarà:

Nostra sanc la llavor siga fecunda,

que en altre temps son fruit done a la pàtria.

Llombart, potser, es veia encarnat en Vicent Peris, i el sentiment agermanat potser esdevenia una metàfora del seu republicanisme o del seu «patriotisme». Però, malgrat l'interés de Llombart per construir un drama històric, no sap substraure's del tot l'atracció popularista, i deixa translluir, de tant en tant, actituds i expressions col-loquials i populars, més adients potser al sainet que al drama de caràcter historicista, en especial en les aparicions femenines a l'obra, que es troben esguitades de formes de parlar molt populars, tot i que Llombart, en aquesta obra, utilitze el vers decasíl.lab, que era considerat més apropiat per a temes més seriosos, i tot imitant el que ja havia fet abans el català Víctor Balaguer, a qui Llombart admirava profundament (Lo Rat 1874: 12). També, perquè aquesta tipologia de vers li permetia un allunyament voluntari del sainet de caire còmic, que usava tradicionalment l'heptasíl.lab (Sansano 2005: 192). I això perquè, a la fi, es pot veure clarament que Llombart, tot i aprofitar el teatre com a mitjà de comunicació de masses, sembla que va reservar el castellà per a temes més «elevats», mentre que es va servir del català sols per a arguments banals $\mathrm{i}$ còmics, tret del cas de Lo darrer agermanat que sembla que, possiblement per aquesta particularitat també, no va assolir la repercusió als escenaris valencians que pretenia el seu autor. De fet, l'obra no es va representar fins el 1884 i solament al Teatre-café del carrer de Russafa, la qual cosa equival a dir que no va passar de l'àmbit popular i favorable a les idees republicanes de Llombart, i que, ni les preocupacions erudites ni el tema historicista triat per l'autor van ser suficients per arribar a la societat «benpensant» que podia freqüentar altres espais teatrals de la capital, cosa que aprofita Sansano (2005: 194) per titlar de «fracàs» aquell intent de Llombart.

Tanmateix, si la societat del seu temps no va saber valorar correctament aquella peça teatral, cal dir que, sense dubte, de tota la producció llombartiana, aquest escrit és pràcticament el que millor ha resistit el pas del temps. De fet, a més de les dues edicions que ha conegut recentment (Atienza 2005 i Llombart 2006a), Lo darrer agermanat s'ha arribat a proposar per tal retornar-lo als escenaris, tot i que, això sí, des de l'àmbit privilegiat de la Universitat Catalana d'Estiu, el 2006. ${ }^{8}$

De fet, si el text encara atrau els lectors és perquè es tracta no sols d'una obra discreta, amb més voluntat que recursos, sinó d'un text amb la força suficient com per matenir l'atenció de qui s'hi acosta. I també perquè, si contemplem aquell text dins el conjunt de la producció teatral llombartiana, es pot afirmar que ens trobem davant la peça teatral de major volada i de més maduresa artística de

${ }^{8}$ Vegeu-ne l'anunci a http://annanoticies.com/2006/08/22/ 
l'autor. Així, l'«episodi dramàtic en un acte», com l'anomena el seu autor s'estructura en vint escenes dins l' «acte únic» on Llombart s'esforça per mantenir l'atenció de l'espectador a base de combinar fragments més populars i de regust més castís amb altres on destaca la tendresa dels seus personatges o fa ressaltar el dramatisme, les actituds heroiques dels protagonistes del drama a què es troben abocats sense remei.

Així, l'escena I, que funciona de preàmbul de l'obra, és tota ocupada pel monòleg de Llorenç, un dels capitans del bàndol dels agermanats. Aquest, amb un llenguatge que presenta una certa solemnitat, aprofita els moments anteriors a l'alba per fer un brevíssim resum de la situació en què es troben les tropes agermanades, assetjades a la ciutat de València i, més concretament, aquelles que resisteixen a la casa de Vicent Peris, emblemàtic cabdill de la Germania. Llorenç, sense haver pogut domir en tota la nit ( «Ans de la nit a desvanir les boires / la llum vingué de la naixent aubada, / que entornar poguí els ulls...»), es troba preocupat per la situació, lloa els soldats del seu exèrcit i, al soliloqui inicial que vol donar un to greu a l'obra, es lamenta de la incertesa del temps: "Què nos aguarda?» — arriba a exclamar. Els agermanats de València es troben perduts, si no arriben els reforços de Xàtiva i d'Alzira, mentre el virrei ja compta amb l'auxili del que Llombart denomina «estrangera tropa castellana». El dia ja comença i la llum ho ompli tot: les tropes són despertades a toc de tambor, cosa que aprofitarà per recordar en veu alta Llorenç la victòria d'Almenara, dels agermanats sobre els «tisnats» —els «mascarats», mot amb què es coneixien els partidaris del bàndol antiagermanat-; i la de Peris a Gandia, ensenyorant-se fins i tot del palau ducal. L'escena II mostra la presència del Xiquet, que toca el tambor per despertar la tropa, i com Llorenç i Ambròs - un mestre veterà dels agermanats-, el fan callar, per tal de respectar el descans de Peris, que també ha passat la nit en vetla. Les escenes III i IV, de caràcter més «acolorit» — com assenyala Sansano (2005: 194) - , fan aparéixer en escena un personatge femení, Cristiana, que és mostrada com una brava lluïtadora del costat dels agermanats, en recontar episodis dels enfrontaments armats de Xàtiva i d'Alzira, en un ambient de camaraderia de taverna, amb glops de vi i indirectes eròtiques cap a la dona, malgrat que Llombart s'encarrega de llançar la sospita de la traïció sobre ella quan, a l'escena V, fa exclamar a Ambròs: «No nos resulte mora, eixa Cristiana!», en al·lusió als recels que sent envers ella. A l'escena VI, un nou monòleg de Llorenç ens fa saber que el dia ja ha arribat i que la gent es prepara a la batalla, lamentant, fins i tot abans que es produesquen, les pèrdues que generarà aquesta: «Quants orfes quedaran, i quantes viudes! / Quants de desamparats!» Les escenes VII i VIII són només preparatòries de les següents i són, clarament, de caire informatiu: s'acosta un frare amb l'ambaixada dels antiagermanats i Peris i els seus reafermen la seua voluntat d'escoltar-lo, encara que sense esperances d'arribar a bon port.

A partir de l'escena IX, i fins la XV, el to de l'obra de Llombart és molt més dramàtic $i$, en alguns punts, fins i tot sentimental. De fet a la primera d'aquestes escenes Peris, en un monòleg reflexiu, anticipa la desfeta final:

Jo sé que som perduts, puix sé que tenen

junyida a son poder ma gent escassa... 
Jo sé que, dins de poc, ma negra estrela fatal va a ser-me en lo carrer de Gràcia... Vençuts anem a ser per los vils nobles que al fi desplegaran son odi i ràbia! Emperò, al manco, morirem en honra, ab tesó defenent la santa causa del poble valencià, que pau, justícia i germania als cavallers reclama. Eixa és nostra ambició! Muigam com hèroes de nostres furs sagrats en la demanda i encara que vençuts, la història un dia ja enaltirà lo que en València es faça per eixos menestrals que no consenten vórer sa dignitat així ultratjada.

A l'escena $\mathrm{X}$ es desenvoluparà un diàleg entre Vicent Peris i el Pare Galcerà on aquest segon retraurà al capità de la Germania l'actuació contra els vassalls musulmans dels senyors valencians, als quals els agermanats acristianaren «per força o grat», i donant-los mort en molts casos, després. Peris es defensa, i ataca l'actitud del virrei, que hauria «prevengut lo rei», al qual se l'ataca «perquè en València als ciutadans tractar-nos / volgué com de Castella al poble tracta». Davant l'actuació del monarca, que donà suport als nobles però que també va mantenir tractes amb els revoltats, que mai negaren l'autoritat reial, el Pare Galcerà exclama - en un crit que sona més contemporani de Llombart que de Peris-: «Tal, verdaderament, són els polítics. / Son art és vore a qui millor s'enganya.» I segueix, per aconseguir que Peris deixe les armes, pintant un despietat futur per a la vídua i els fills de l'agermanat, amb tocs certament sangonosos:

Pensa en tons fills, Vicent, que en tu a son pare

cridaran, dins de poc, i tal vegada

no existirà... que a quansevol punt públic

un dia els portarà sa sort amarga

i giraran, plens de terror, la vista

perquè voran allí la ensangrentada,

ja negra, testa del que fon son pare...

Vicent Peris, davant aquella imatge profètica, abraça el seu fillet encara adormit, en una mostra de tendresa de l'agermanat, que el fa més humà i que pretén, així, guanyar-se l'afecte del públic. L'intent del Pare Galcerà no obtindrà el fruit que esperava i el capellà sembla ressignar-se i acceptar el fracàs de la seua ambaixada, atés que Peris es nega a rendir-se a les forces del virrei. Però a l'escena XI apareix Àngela — esposa del cabdill agermanat-i, per contra del que podríem esperar, és aquesta qui dóna ànims per al marit a resistir fins a la fi. De fet, Àngela demana al marit que s'enfronte als nobles adduint qüestions personals: un noble va requerir-la d'amors i ella es va negar, veent-se així atacada pels altres «senyors nobles», que pretenien doblegar-la als desitjos deshonestos del primer. Àngela, després, vol que els nobles demanen perdó pel dany causat al poble, i és el Pare Galcerà qui s'estranya d'aquella petició, amb què 
l'esposa de Peris quasi sentencia: «Sempre lo poble té que ser qui paga! / Les dones ploraran, sí, però els homes / cumpliran lo seu deure...». A la qual cosa contesta Peris: «Jo no tem la mort, la desafie! / Jo no tem lo desterro ni sa infàmia! / Sols m'esglaia deixar-vos una herència / de llàgrimes i dol...» Una herència que és acceptada de grat per Àngela. A l'escena XI, el marqués de Los Vélez, «aqueixe jabalí de terra estranya», envia un missatge a Peris que, en ser llegit pel Pare Galcerà — l'únic que sap llegir dels presents — l'indigna fins al punt que sembla passar-se'n al bàndol dels agermants. Resulta ben significatiu el tractament del virrei i dels seus seguidors - els exèrcits castellans- que fa Llombart, en aquesta escena. Així, Ambròs denomina de nou «jabalí» al marqués de Los Vélez i demana

estrangular demprés, una per una, eixes goles de llop, plenes de ràbia, que d'estranger país sols a tragar-se venen la llibertat de nostra pàtria.

El Pare Galcerà es lamenta, fins i tot, de les condicions que demana el bàndol antiagermanat i exclama la seua sorpresa, que suscita un diàleg que llança a la lluïta els agermanats:

Pare Galcerà: Jo dubte que eixa intimació ser puga

per lo senyor governador dictada

i molt menys, ni ara ni mai, podré compendre

que siga un valencià qui feta l'haja.

Peris: De castellans està la ciutat plena.

Pare Galcerà: Déu, puix, nos protegeixca!

Ambròs: Coltellades haurà! (A Peris)

Peris: Sí, Ambròs, que vegen,

ja que de destruir los furs se tracta,

que obrir precís abans serà un sepulcre

a on caiguen nobles i plebeus a manta.

Ambròs: Vixca València! Avant i manco llàgrimes! (A les dones)

Puix, plorar per plorar, la cosa és clara,

val més vestir de dol per los que muiguen

guerrejant, front a front d'eixa canalla,

que per aquells a qui demà els aprete

en lo Mercat lo coll Morro de Vaca.

Les escenes XIII i XIV són dos moments en què Llombart aprofita per mostrar l'adhesió a la causa agermanada d'Ambròs i d'Àngela que, en aquest darrer cas, assoleix pinzellades de romanticisme $\mathrm{i}$ heroïcitat que esdevindran profètiques. Mentre Peris pretén que l'esposa i els fills se'n vagen, ella preferirà restar-hi i afrontar la mateixa sort que el marit, el qual, en acomiadar-se de la seua dona, només li dóna «un petit bolsillo», que és «mon únic tresor», cosa que aprofita Llombart per a remarcar l'honestedat de Vicent Peris, el qual es queixa, dient en aquell moment que «encara alguns de lladre me motetgen!» 
A les cinc escenes restants, de la XV a la XX, el to de l'obra va in crescendo per dotar de major dramatisme el desenvolupament de l'acció, que es precipita cap al final més desastrós per al bàndol dels agermanats. De fet, després que Peris aconsegueix que part de la seua famíla se'n vaja (escena XV), tret de la filla, Maria, que prefereix romandre amb el pare i l'enamorat seu, Llorenç (escena XVI), es produeix l'última ambaixada dels antiagermanats, amb la presència del marqués de Cenete, sense fruit, a l'escena XVII. La veu de Vicent Peris apareix ací clarament defensant els interessos valencians - i els furs, especialment. Així, Peris arriba a dir:

la perdició de nostre reine tenen los estrangers ja decretada, perquè ja ab los de Moya i de los Vélez, vostre germà, que nostres furs maltracta, conta dret la ciutat ha invadit tota, cregut de què ab sos terços li mancara gent per a véncer les ardides forces dels populars, que ell tilda de canalla. I en tant, de mitjaner vós feu l'ofici.

Mendoza nostres caps pregonar mana... No és justícia ni pau lo que se busca...

Cregau-me, monsenyor, que vos enganya!

Davant l'afirmació de sobèrbia per part de Peris feta pel marqués de Cenete, el cabdill agermanat, encara, respondrà:

No, no és orgull: és dignitat. Del poble jo a ser lo salvador sols aspirava.

Mes no ha permés lo cel que jo en València la redemptora creu plantificara!

Nostra sang la llavor siga fecunda que en altre temps son fruit done a la pàtria! Retireu-vos, marqués, retireu-vos... Brille de Déu la providència sàbia! Sols, monsenyor, que declareu desitge, ans que al carrer ixcau de nostra casa, per a conhort, almenys, d'aquestos pobres plebeus que morir saben per la pàtria, si al peu mateix de sa sangrienta forca serà la tomba de sos furs cavada.

I el marqués de Cenete respon:

No, Vicent Peris, no. Per a defendre-los sempre els nobles tindrem a punt la espasa. Per la bona memòria vos ho jure del rei Conqueridor. 
L'exaltació patriòtica no només està en boca de Peris - i fins i tot de Cenete, en el punt tocant als furs-, sinó que Ambròs arriba a demanar que «ixquen los castellans fora de València». Però Cristiana —el personatge femení totalment inventat per Llombart-, que a l'escena XVII demana en un moment donat que es penje Cenete, més tard desencadena la fi, ja que se'ns la presenta com la dona que a les cròniques apareix llançant un cantell o un test a Cenete, i causantli la mort, que és el detonant de l'enfrontament final contra els agermanats la casa de Vicent Peris, que és botada foc i on moren tots, en les escenes últimes, que es tanquen amb la lapidària sentència d'Ambròs, que clou l'obra de Llombart:

\author{
Botxins del poble: \\ hi ha un tribunal de Déu a on tot se paga! \\ Si haveu sacrificat a vostres ires \\ al que fon de València la esperança. \\ i ab ell lo pensament espant dels nobles, \\ ferestament esteu destruïnt ara. \\ La venjadora història dirà als segles \\ quan al poble vençut justícia faça: \\ «Caigué Peris i ab ell la Germania \\ morí traïdorament assessinada!».
}

El desenvolupament del drama ideat per Llombart, en essència, segueix de manera bàsica el que relaten les fonts a què va poder accedir l'autor. De fet, Llombart ho fa palés quan, a la taula de les dramatis personae, assenyala en nota quins d'aquells porten noms «documentats» i quins no i, encara, tanca l'explicació tot dient que «S'ham servit en tot lo possible de la Història» (Llombart 2006a: 54). Però, en especial, Llombart va tenir present el segon volum de les Décadas d'Escolano/Perales (1879, II), que just acabava de publicar-se uns anys abans, i tal com el mateix Llombart declara més o menys explícitament en notes que volen ser informatives al seu escrit (Llombart 2006a: 54, 60, 72). També, molt segurament va tenir a la vista el breu relat d'aquell episodi fet pel cronista romàntic Vicent Boix a la seua Historia de la ciudad y reino de Valencia (1845, I: 382-383), com es descobreix, fins i tot, en la semblança dels mots usats per Llombart, en referir la mort de Peris. Així, a la nota del renaixencista que explica com es va permetre una llicència literària, tot canviant el lloc de la mort de l'agermanat, llegim que «l'assessinaren bàrbarament» (Llombart 2007: 96). A l'obra de Vicent Boix (1845, II: 383) és llegeix: «fue asesinado bárbaramente». Però, no només, sinó que Llombart, en el seu interés per no solament entretenir un públic fidel, sinó també formar-lo i, encara, aprofitar els seus escrits per agitar consciències a favor de la causa «patriòtica» 0 «valenciana», assenyala:

Fins lo darrer segle ha dut aquesta placeta lo nom de l'insigne plebeu Vicent Peris. Per quina causa va desaparéixer? Què significa l'obscur nom de Galindo que en l'actualitat porta? No ham aconseguit averiguar-ho. En canvi, hui que l'excel-lentíssim ajuntament de València, sense to ni so, ha pegat en variar-los, en molts carrers y places, quant indicada pareixia per los memorables aconteiximents de què fon sangrient teatre la referida placeta, a recabalar lo gloriós 
nom de Vicent Peris que abans tan justament ostentava, s'ha respectat lo de Galindo, que poc o res significa, batejant — pareix mentira! — lo de l'Estornut — carreró sense cases — ab lo nom gloriós de Vicent Peris.

Ignorarien, els que tal disposaren, que lo que és hui placeta de Galindo fon un dia solar de la casa a on en lo darrer dia de sa existència coronà Vicent Peris son nom d'eterna glòria? Serà, acàs, que sabent-ho, com no pot menys de ser, obraren inspirats per lo mesquí esperit de la passió política? No ho sabem. Lo que sí que és cert, que a pesar d'haver manifestat la premsa periòdica en diferents ocasions son lloable desig de què tornara a la citada placeta de Galindo lo nom de Vicent Peris, s'ha obrat tan desatinadament que bé podem qualificarho ací de sacrilegi històric (Llombart 2006a: 54-55). ${ }^{9}$

O, més avall, quan informa en nota de la vertadera fi de Peris, no s'està de lamentar la desídia dels valencians davant el que ell considera un heroi nacional:

En altre país, hui que ha aplegat l'hora de les grans vindicacions, no sols inscrivint lo nom d'aquell màrtir de la llibertat en una pobra rajoleta de Manises, sinó alçant-se-li una estàtua en aquell punt s'haguera honrat sa imperecedera memòria! Este és lo patriotisme d'alguns homes! (Llombart 2006a: 98).

En definitiva, doncs, malgrat totes les limitacions que la crítica moderna ha vist a l'obra teatral de Llombart i que la producció dramàtica d'aquell cappare de la Renaixença sembla que no va arribar a trascendir més enllà deels ambients més populars (Sansano 2005: 197-198), caldria destacar també que Lo darrer agermanat és un text d'ambicions literàries relativament cultes i això es pot notar tant en l'ús del metre (decasílllab) com en la presència de freqüents arcaismes a la llengua emprada. Per altra banda, hi ha una clara pretensió de reivindicar un episodi històric nacional entre els valencians del moment, no sols presentant l'agermanat Vicent Peris com un defensor de les classes populars i d'un cert republicanisme avant la lettre, sinó també com un defensor dels furs i de les lleis valencianes contra la presència dels castellans, que són clarament considerats com «estrangers» en diferents passatges de l'obra. Una actitud clarament romàntica. Encara, el remarcable vessant d'agitador cultural i reivindicatiu de Llombart pot veure's en l'evident voluntat de recuperació que proposa de l'espai real on es va desenvolupar el seu drama per a la memòria col-lectiva dels valencians. Tot plegat, en aquest text es pot veure el millor Llombart: conjugà erudició - dins els límits de l'autor-, creació — amb clara voluntat literària — i reivindicació política — des de l'òptica cultural de la Renaixença que ell proposava-, per tal d'aconseguir un producte digne com és Lo darrer agermanat. Si comparem aquella obra amb altres semblants de la Renaixença catalana, evidentment el nivell assolit per Llombart no és tan «destacable», atesa la relativa simplicitat, fruit sens dubte de la seua limitada formació cultu-

9 Vicent Boix (1845, II: 383), per cert, en nota de peu de pàgina indica que «desde entonces quedó la plazuela llamada de Galindo, y antiguamente de les Pelaes». Aquesta nota de Boix, per altra banda, apareix, pràcticament igual, traduïda en català, segurament pel mateix Llombart, a Lo Rat Penat. Calendari llemosí, del 1883, a manera de notícia (Lo Rat 1883: 106). 
ral. Però la figura de Llombart destaca al País Valencià de la segona meitat del XIX, clarament, pels seus esforços reivindicatius de la llengua i de la cultura pròpies i, en part, aquell seu interés encara és ben recordat entre nosaltres, com s'ha posat de relleu no fa encara massa anys per bona part de les institucions valencianes (Escartí/Estrela 2008).

\section{BIBLIOGRAFÍA}

AHUIR, Artur, «Les memòries d'un literat. Una desconeguda font biogràfica de Constantí Llombart. Les notes de Ramon Andrés Cabrelles», dins EsCARTí, Vicent Josep / Roca Ricart, Rafael (eds.): Constantí Llombart i el seu temps, Acadèmia Valenciana de la Llengua, València, 2005, pp. 256-303.

_- Almanaque de Las Provincias para 1894, Federico Doménech, València, 1893.

ARChILÉS, Francesc / MARTí, Manuel, «Renaixença i identitats nacionals al País Valencià», dins Bernat $i$ Baldoví $i$ el seu temps, Institut Interuniversitari de Filologia Valenciana, València, 2002, pp. 51-71.

Atienza, Antoni, Teatre valencià de la Germania, L'Oronella, València, 2000.

BLASCO, Ricard, Estudis sobre la literatura del País Valencià (1859-1936), Institut de Filologia Valenciana, València, 1984.

_, Constantí Llombart i «Lo Rat Penat. Periòdich lliterari quincenal» (1884-1885), Diputació de València, València, 1985.

—, «Llengua i pàtria al País Valencià durant la Renaixença», Caplletra, núm. 4 (1988), pp. 43-67.

Borx, Vicente, Historia de la ciudad y reino de Valencia, 3 vols., Benet Montfort, València, 1845-1847.

Cucó, Alfons, El valencianisme polític (1874-1936), Afers, Catarroja-Barcelona, 1999.

DD. AA., Historia de lo Rat Penat, Lo Rat Penat, València, 2000

DD. AA., Homenage a en Constantí Llombart: composicions llegides en la seció verificada en son honor lo día 11 de maig de 1893, en Castelló de la Plana, Impremta de C. J. Forcada, Castelló de la Plana, 1893.

EsCarTí, Vicent Josep, «Les idees de Constantí Llombart a través de Lo Rat penat. Calendari llemosí», dins EsCARTí, Vicent Josep / Roca RICART, Rafael (eds.): Constantí Llombart i el seu temps, Acadèmia Valenciana de la Llengua, València, 2005, pp. 136-165.

EscarTí, Vicent Josep / Roca Ricart, Rafael (eds.): Constantí Llombart i el seu temps, València, Acadèmia Valenciana de la Llengua, 2005.

EsCARTí, Vicent Josep / Estrela, Josep Enric, «Sobre l'Any Constantí Llombart (País Valencià, 2005)», Anuari Verdaguer. Revista d'Estudis Literaris del segle XIX, núm. 15 (2008), pp. 435-448.

Escolano, Gaspar / Perales, Juan Bautista, Décadas de la Historia de la insigne y coronada ciudad y reino de Valencia, 3 vols., Terraza Aliena y Compañía Editores, València/Madrid, 1878-1880. 
Estrela, Josep Enric, «L'interés pel passat històric a Lo Rat Penat. Calendari llemosí», dins EsCARTí, Vicent Josep / RocA RICART, Rafael (eds.): Constantí Llombart i el seu temps, Acadèmia Valenciana de la Llengua, València, 2005, pp. 166-185.

Fogués Cogollos, José F., Efemérides carcagentinas, Imprenta del Asilo de Huérfanos del Sagrado Corazón de Jesús, Madrid, 1902.

GuARDiola I SAVAll, Maria Isabel, «L'aportació de Llombart al diccionari d'Escrig», dins EsCARTí, Vicent Josep / RoCA RICART, Rafael (eds.): Constantí Llombart i el seu temps, Acadèmia Valenciana de la Llengua, València, 2005, pp. 232-255.

Guarner, Lluís, «Pròleg» a Llorente Olivares, Teodor, Poesia valenciana completa, Eliseu Climent, València, 1983, pp. 17-90

Igual ÚBEDA, Antonio, Història de lo Rat-Penat, Ajuntament de València, València, 1959.

LeOn RocA, José Luis, Constantí Llombart, Lo Rat Penat, València, 1995.

Llombart, Constantí, Himno que el Orfeón republicano de Valencia dedica al eminente orador Emilio Castelar, con motivo de su llegada a esta población, Josep Barberà, València, 1871.

—, Niu d'abelles. Epigrames llemosins, Josep Peydró, València, 1872.

—, Abelles y abellerols. Sent y un epigrames, Emili Pasqual, València 1878.

—, Los fills de la morta-viva, Emili Pasqual, València, 1883.

—, La copa d'argent, Josep Ortega, València, 1887

—, «Mis primeros versos», dins Las Provincias. Almanaque para 1889, València, 1888, p. 302.

—, Crònica de la revolució cantonal, a cura de R. Aracil, Eliseu Climent, València, 1973.

—, Lo darrer agermanat, a cura de V. J. Escartí, Alfons el Magnànim, València, 2006a.

-, Poesies valencianes, a cura de Rafael Roca Ricart, Acadèmia Valenciana de la Llengua, València, 2006b.

LluCh Soler, Manuel, Constantino Llombart. Apuntes biográficos, València, Manuel Vilar, 1879.

LloRIS I VALDÉS, Manuel, Constantí Llombart, Alfons el Magnànim, València, 1982.

Lo Rat Penat. Calendari llemosí corresponent al present any de 1875. Compost ab la distinguida colaboració dels més reputats escriptors de València, de Catalunya y de les Illes Balears per En Constantí Llombart, València, Pasqual Aguilar, 1874-1884.

Martí Mestre, Joaquim, «Constantí Llombart i la llengua», Escartí, Vicent Josep / Roca RICART, Rafael (eds.): Constantí Llombart i el seu temps, Acadèmia Valenciana de la Llengua, València, 2005, pp. 200-231.

Navarro CABAnEs, Josep, Catàlec bibliogràfic de la prensa valenciana, Diario de Valencia, València, 1928

PÉREZ I MORAGÓN, Francesc, «Constantí Llombart, el pobre de les grans empreses», dins Escartí, Vicent Josep / RocA Ricart, Rafael (eds.): Constantí Llombart i el seu temps, Acadèmia Valenciana de la Llengua, València, 2005, pp. 36-55. 
ROCA RICART, Rafael, Teodor Llorente, el darrer patriarca, Institut Interuniversitari de Filologia Valenciana / Bromera, Alzira, 2004.

-, Teodor Llorente, líder de la Renaixença valenciana, Publicacions de la Universitat de València, València, 2007.

—, «Introducció» a Llombart, Constantí, Poesies valencianes, Acadèmia Valenciana de la Llengua, València, 2006.

SANCHIS GUARNER, Manuel, El sector progressista de la Renaixença valenciana, Institut de Filologia Valenciana, València, 1985.

SANSANO, Gabriel, «L'obra dramàtica de Llombart», EscarTí, Vicent Josep / Roca RICART, Rafael (eds.): Constantí Llombart i el seu temps, Acadèmia Valenciana de la Llengua, València, 2005, pp. 184-199.

Simbor RoIG, Vicent, Els orígens de la Renaixença valenciana, Institut de Filologia Valenciana, València, 1980.

—, «La Renaixença al País Valencià», Caplletra, núm. 4 (1988), pp. 9-41.

VERGER, Eduard-J.: «La poesia valenciana de la Restauració (1874-1902)», Caplletra, núm. 4 (1988), pp. 79-89. 